\title{
Elbasanishtja me syrin e një gjermani - Rrëfim i Gustav Weigand-it
}

\section{(Gustav Weigand dhe vepra e tij “Albanesische Grammatik”)}

Emine Sadiku

\section{Si mësova shqip}

Shqipen fillova ta studioj teorikisht me gramatikën e G. Meyer, pastaj praktikisht vazhdova në Manastir te zoti Qiriazi, me të cilin u njoha dhe ushtrova toskërishten. Në dimrin e vitit 1889- 1890 në Athinë me një student nga Elbasani, Efraim Gjini, u njoha me të folmen e Elbasanit, që i përket dialektit të gegërishtes jugore. Më vonë mbajta në universitet shumë kurse mbi gramatikën dhe historinë e gjuhës shqipe. Eksperienca që fitova gjatë këtyre kurseve, ma bëri të qartë se mungonte një mjet i rëndësishëm që siguron suksesin, një gramatikë praktike e gjuhës shqipe. Si gramatika e G. Meyer, ashtu dhe Gramatika e Gj. Pekmezit, botuar në vitin 1908, nuk janë të përshtatshme për këtë funksion. Prandaj mora përsipër ta kryeja vetë këtë detyrë. Në vitin 1909, në verë, shkova në Durrës, Tiranë dhe Elbasan. Atje bëra studimet e nevojshme, mbi bazën e të cilave ndërtova gramatikën. Në pranverën e vitit 1912 u nisa prapë për në Elbasan. Këtë udhëtim, ashtu si dhe udhëtimin e parë e mbështeti financiarisht fondacioni "Albrecht" (të cilin e falenderoj përzemërsisht). Udhëtimi në Elbasan kishte për qëllim plotësimin e gramatikës së konceptuar dhe korrigjimin e vendeve të caktuara në tekst. Duhej që gjithçka e konceptuar dhe e shkruar nga një joshqiptar të kishte një pamje korrekte shqipe. Zoti Simon Shuteriqi i kaloi me mua të gjitha materialet e paraqitura. Një ndihmë të madhe më ofroi dhe kryeprifti, papa George Germanos. Si 


\section{Albanon}

\section{Revistë kulturore}

herën e parë dhe herën e dytë më siguroi një banesë mikpritëse. Banorët e tjerë të shtëpisë, ku gjendej banesa ime, si dhe vizitorë të rastit, miq e të njohur të tjerë më ndihmuan në punën time duke bërë të mundur shmangien e informacionit të njëanshëm.

\section{E folmja e Elbasanit si material gjuhësor-bazë i analizave gramatikore}

Tani mund të më pyesni: pse vura si lëndë-bazë të gramatikës sime, material gjuhësor nga dialekti gegërisht jugor dhe pikërisht të folmen e Elbasanit?

Për arsye të ndryshme. Para së gjithash duhej të zgjidhja një të folme (dialekt) qendrore që është e kuptueshme si për toskët, ashtu dhe për gegët. E folmja e Elbasanit (si dhe dialekti gegërisht jugor) e përmbushte këtë kusht, mund të merrej në shqyrtim, edhe pse nuk përdorej asokohe si gjuhë letrare. Qendra e Shqipërisë është kryesisht muhamedane. Fanatizmi fetar nuk lejoi zhvillimin dhe fiksimin e gjuhës letrare kombëtare në këtë trevë. Ndërsa në Veri propaganda katolike mbështeste vazhdimisht zhvillimin e një literature të shkruar në alfabetin latin dhe në një gjuhë letrare-kombëtare. Në jug, në toskëri, ndërkohë ndihej ndikimi i shkollës, kulturës dhe propagandës greke. Edhe këtu filloi të shkruhej gjuha amtare, por në fillim pa synuar ndonjë propagandë nacionale, se shumica e toskëve ortodoksë ishin në anën e Greqisë. Po kur filloi të përhapej një propagandë e zjarrtë nacionale ndër toskët, atëherë ortodoksët e gegërisë jugore mbështetën idenë e toskërishtes si gjuhë letrare. Ishte fjala për një të folme si ajo e Korçës. Ky variant si në pikëpamje të formave gramatikore, ashtu dhe në leksik, paraqet vështirësi të mëdha për të folmet gegërishte veriore. Nga ana tjetër gegërishtja veriore (si shkodranishtja) me synkopat dhe asimilimet e palataleve, ishte akoma më e pakuptueshme për toskët. Këto vështirësi mund të mënjanohen, po të vendoset në qendër të formimit të letrarishtes gjuha e gegëve jugorë. Elbasani me pozitën e tij qendrore është një zonë krejt shqiptare. Ai gjendet në anë të rrugës Egnatia, në luginën e Shkumbinit, ku kryqëzohen rrugët për në Tiranë, Durrës, Berat dhe Vlorë. Ai është nominuar për t’u bërë kryeqytet i Shqipërisë së lirë. Në kohën, që isha unë aty, në kohën, që po shkruaj këto shënime, nuk ishte kryeqytet. Por i ka të gjitha shanset për t’u bërë. Me hapjen e një seminari për mësues në këtë qytet është bërë hapi më i mirë për formimin e një gjuhe të përbashkët shkrimi të mbështetur në dialektin e gegërishtes jugore, ashtu siç flitet në zonën midis Elbasanit, Durrësit, Krujës, Dibrës, Strugës. 
Dialekti gegërisht jugor, që nuk duhet konceptuar si një përzierje gegërishttoskërisht, por duhet të ruajë krejt karakterin e tij fonetik-gramatikor, është jo vetëm i kuptueshëm për të gjithë shqiptarët, por dhe më i lehti për t'u mësuar. Thjeshtësia e fleksionit nominal dhe pronominal përkundrejt formave të shumta në toskërisht, numri i vogël i formave verbale, shkurtësia e participit, janë lehtësira të konsiderueshme në nxënien e variantit të gegërishtes jugore ndaj atij tosk.

Fakti që gegërishtja nuk tingëllon aq bukur, që paraqet më shumë vështirësi në shqiptim për të huajt, vlen të shpërfillet kundrejt avantazheve të numëruara që kanë të bëjnë direkt me ekonominë ligjërimore.

\section{Disa fjalë mbi gramatikën e gjuhës shqipe të G. Weigand}

Lidhur me librin-gramatikën e Weigandit: në kapitullin e parë trajtohet shqiptimi. Ne tetë kapitujt në vijim prezantohen pjesët e ligjëratës. Një trajtim i veçantë i bëhet klasës më të vështirë ndër pjesët e ligjëratës, përemrit. Këtij i rezervohet po aq vend sa dhe emrit. Vështirësitë, që paraqet analiza e foljeve, janë kapërcyer duke e trajtuar foljen e duke i shpërndarë paradigmat e fleksionit të saj gradualisht në të gjithë pjesën e parë. Kështu fiksohen në kujtesë anomalitë, përjashtimet nga rregulli. Pjesa e dytë merret vetëm me fleksionin, me mënyrat, aspektin, përdorimin e kohëve; me sintaksën e foljes, sidomos kur ajo paraqet dukuri jo të zakonshme për të huajt. Në pjesët për emrin, mbiemrin, foljen një kapitull i veçantë i kushtohet fjalëformimit. Eksperienca ka treguar se përmes teorisë dhe praktikës së fjalëformimit mbështetet në një masë të madhe mësimi dhe identifikimi i fjalëve.

Ndodh të kapërcehen kufijtë e kësaj gramatike duke kaluar në shpjegime etimologjike ose krahasuese ballkanike. Për këtë autori thotë se trajtime të tilla mund të shpërfillen nga të interesuarit, sepse ato nuk janë të domosdoshme, edhe pse shumë të dobishme. Kudo, krahas shpjegimeve gramatikore, ofrohen në sasi të mjaftueshme ushtrime që synojnë ushtrimin dhe praktikimin e gramatikës, e gjuhës. Është e domosdoshme që njohja dhe fiksimi i gramatikës të mbështetet në ushtrime. Përkthimi i ushtrimeve mundëson mësimin autodidakt. Ushtrimet krejt elementare të leksioneve të para përmbajnë fjali të marra nga ligjërimi bisedor. Kjo mundësohet nga trajtimi i foljes qysh në fillim të kursit. 


\section{Albanon}

\section{Revistë kulturore}

Ka raste, ku shpjegimi, që mund të bëhej me anë të rregullave gramatikore, jepet qartë nëpërmjet ushtrimeve. P.sh.: për numërorin, për sqarimin e kategorisë, janë dhënë tri lloje ushtrimesh të bollshme. E njëjta gjë është bërë dhe me përemrin.

Shembujt e marrë nga Bibla, që gjenden në pjesën e tretë, janë marrë nga “Katër ungjillat" e Kristoforidhit (botuar në Kostandinopol, më 1866). Ato i janë përshtatur në shkrim e në leksik të folmes së Elbasanit. Në gjuhën e përditshme autori nuk mund të mblidhte thënie biblike.

Tekstet e përfshira në pjesën e tretë, të mbledhura në literaturë popullore, e tregojnë më së miri, më mirë se në shembujt e izoluar, karakterin e gegërishtes jugore. Vihet re se sa pa rëndësi janë dallimet gjuhësore midis së folmeve të Tiranës dhe Durrësit kundrejt asaj të Elbasanit.

\section{"Fillimisht doja ti i bashkëlidhja gramatikës dhe një glosar, por kisha grumbulluar} shumë material, që i kalonte kufjtë e një glosari gramatikor".

Gjatë udhëtimeve në Shqipëri, Weigand kishte grumbulluar shumë fjalë dhe shumë material gjuhësor, të cilin e përdori për nevojat e komunikimit. Një volum i tillë materiali gjuhësor mund të përdorej dhe nga udhëtarët, vizitorë të Shqipërisë; por edhe nga dijetarë me interesa teorike për gjuhën. Krahas pjesës shqip-gjermanisht, autori hartoi dhe një pjesë gjermanisht-shqip. Ai thotë se një fjalor i tillë i mungon (dhimbshëm) letërsisë gjuhësore. Fjalori u botua në vitin 1914. Në Fjalor nuk mungojnë shënimet etimologjike se "Dija mbi to është një ndihmë e një lehtësim i madh për fiksimin e fjalësit të Fjalorit”. (Weigand, G.: Albanesische Grammatik, Leipzig, 1913, f. VIII)

Për arsye praktike, autori nuk mbështetet në alfabetin e përdorur nga Gustav Meyer, por në atë të shoqërisë "Bashkimi” (alfabet latin i përdorur në gegërishten veriore). Arsyeja kryesore ishte: nëse shqiptarët do të integroheshin në komunikimin internacional, duhej të përdornin alfabetin latin. Alfabetet e tjera greke, turke apo i S. Frashërit duhej të mos përdoreshin më. Alfabeti i shoqërisë "Bashkimi" ishte konceptuar për shkodranishten, prandaj duhej modifikuar në disa pika. Në çështjen e alfabetit të përdorur, Weigand mori parasysh edhe dëshirën e mendimin e miqve të tij elbasanas. Ata ishin për një alfabet të thjeshtë dhe konsekuent që të mësohej e të praktikohej lehtësisht dhe nga fëmijët shkollarë.

Në hyrjen e shkruar prej tij më, 27 nëntor 1912, Weigand prezanton sistemin e tij alfabetik, ndalet në realizimin prej tij të tingujve dyfishe, të shenjës hundore, të theksit, të shenjimit të gjatësisë së zanoreve etj. 
"Nëse do të shkruash tamam, të shenjosh shqiptimin e shumë muhamedanëve dhe të krishterëve elbasanas, duhet të përdorësh vetëm zanore hundore, se ata $i$ artikulojnë zanoret dhe me pjesëmarrjen e pjesë së pasme të qiellzës (qiellzën e butë)... Grupet mb, nd i mbajta, edhe pse ato tingëllojnë $m, n$; $d$, gartikulohen shumë dobët. Ndërsa grupin mb nuk e kam ruajtur se ai nuk ndryshon fare nga realizimi i tij vetëm me $m$. Kjo është një veçori e gegërishtes qü nuk mund ta ndryshojmë për hir të toskërishtes." (Weigand, G.: Albanesische Grammatik, Leipzig, 1913, f. X). 